\title{
Considerations in the Design of Formable Austenitic Stainless Steels Based on Deformation-Induced Processes
}

\author{
Javad Mola
}

Additional information is available at the end of the chapter

http://dx.doi.org/10.5772/intechopen.70939

\begin{abstract}
The temperature dependence of tensile elongation in austenitic steels is discussed in view of the relationship between the stacking fault energy and deformation-induced processes. It is shown that the maximum tensile elongation is achieved in the vicinity of $M_{d}{ }^{\gamma} \rightarrow{ }^{\alpha^{\prime}}$ temperature. The influence of alloying elements on the temperature dependence of tensile elongation can therefore be analyzed with regard to their influence on the $\mathrm{M}_{\mathrm{d}}{ }^{\gamma} \rightarrow{ }^{\alpha^{\prime}}$ temperature. In this regard, majority of alloying elements including $\mathrm{C}$ and $\mathrm{N}$ decrease the temperature associated with highest tensile elongation. Due to the high efficiency of $\mathrm{C}$ and $\mathrm{N}$ in increasing the stability of austenite, approaches toward the development of high-interstitial austenitic stainless steels containing minimal amounts of substitutional alloying elements are discussed. Finally, some of the challenges associated with the processing of high-interstitial austenitic stainless steels are reviewed.
\end{abstract}

Keywords: deformation-induced processes, transformation-induced plasticity, twinning-induced plasticity, stacking fault energy, tensile elongation, high-interstitial steels

\section{Introduction}

Although austenitic steels are often inferior to ferritic steels in view of the yield strength (YS), they have the potential to work harden to a larger extent which in turn leads to very high ultimate tensile strength (UTS) values. Due to their low YS/UTS ratios, austenitic steels may be used in applications where a high energy absorption capacity rather than a high resistance to yielding is required. In contrast to ferritic steels of which the strain-hardening behavior is not much influenced by varying temperature in the vicinity of room temperature 
and by the addition of common substitutional alloying elements such as $\mathrm{Mn}, \mathrm{Si}, \mathrm{Ni}$, and $\mathrm{Cr}$, the strain-hardening characteristics of austenitic steels are highly sensitive to temperature and chemical composition. Understanding the underlying mechanisms governing the work hardening of austenitic steels and the interrelationships among the material parameters is therefore essential to the effective design of economical austenitic steels. Tremendous austenitic stainless steel design activities at the TU Bergakademie Freiberg, especially in the framework of the Collaborative Research Center 799 (TRIP-matrix composites) running since 2008, have enabled to note the interrelationships summarized in the following sections.

\section{Relationship between the stacking fault energy (SFE) and deformation-induced processes}

Deformation-induced processes in austenitic steels are governed by the SFE. In high Mn austenitic steels, for instance, deformation processes have been proposed to change from the perfect dislocations glide at high SFEs to twinning and then martensite formation at progressively lower SFEs [1]. The SFE depends on the chemical composition and temperature. Numerous empirical relationships have been proposed to describe the influence of alloying elements in austenitic steels on the SFE [2-6]. Nevertheless, care must be taken when using such relationships because their applicability depends on the reliability of the SFE determination method. The inaccuracy of the existing relationships is reflected in the inconsistent coefficients proposed for alloying elements $[2,6]$. Although SFE appears, based on the existing empirical relationships, to have a complex dependence on the chemical composition, it is unanimously known to increase at higher temperatures [7]. The associated changes in the glide mode have important consequences for the deformed microstructures obtained at different temperatures; the wide separation of a/ $6<112>$ Shockley partial dislocations at low temperatures, where the SFE is low, promotes the planar glide of dislocations, for instance by restricting the cross-slip of screw dislocations. The abundance of stacking faults in the microstructure of an Fe-14Cr-5.5Mn-5.5Ni-0.37N (concentrations always in mass-\%) austenitic stainless steel deformed at $-40^{\circ} \mathrm{C}$ is demonstrated in Figure 1. The occurrence of planar glide features such as dislocation pile-ups, stacking faults, twins, and $\varepsilon$-martensite at deformation temperatures associated with low SFEs highlights the traces of $\{111\}$, glide planes. In the example shown in Figure 2, the angular relationships among the traces of glide planes aid to determine the crystallographic orientation of austenite.

As the deformation temperature increases, the reduced separation of partial dislocations and the possibility of constriction increase the three-dimensional mobility of dislocations and a gradual transition to the wavy glide mode follows [8]. Deformed microstructures under wavy glide conditions are characterized by dislocation cell structures with almost dislocation-free interiors surrounded by dislocation rotation boundaries $[9,10]$. Dislocation cell formation in an Fe-18Cr-7Mn-9Ni-0.43C stainless steel deformed at $200^{\circ} \mathrm{C}$ is demonstrated in Figure 3. Further examples of austenitic stainless steel microstructures formed at various deformation temperatures may be found in [10-16]. 


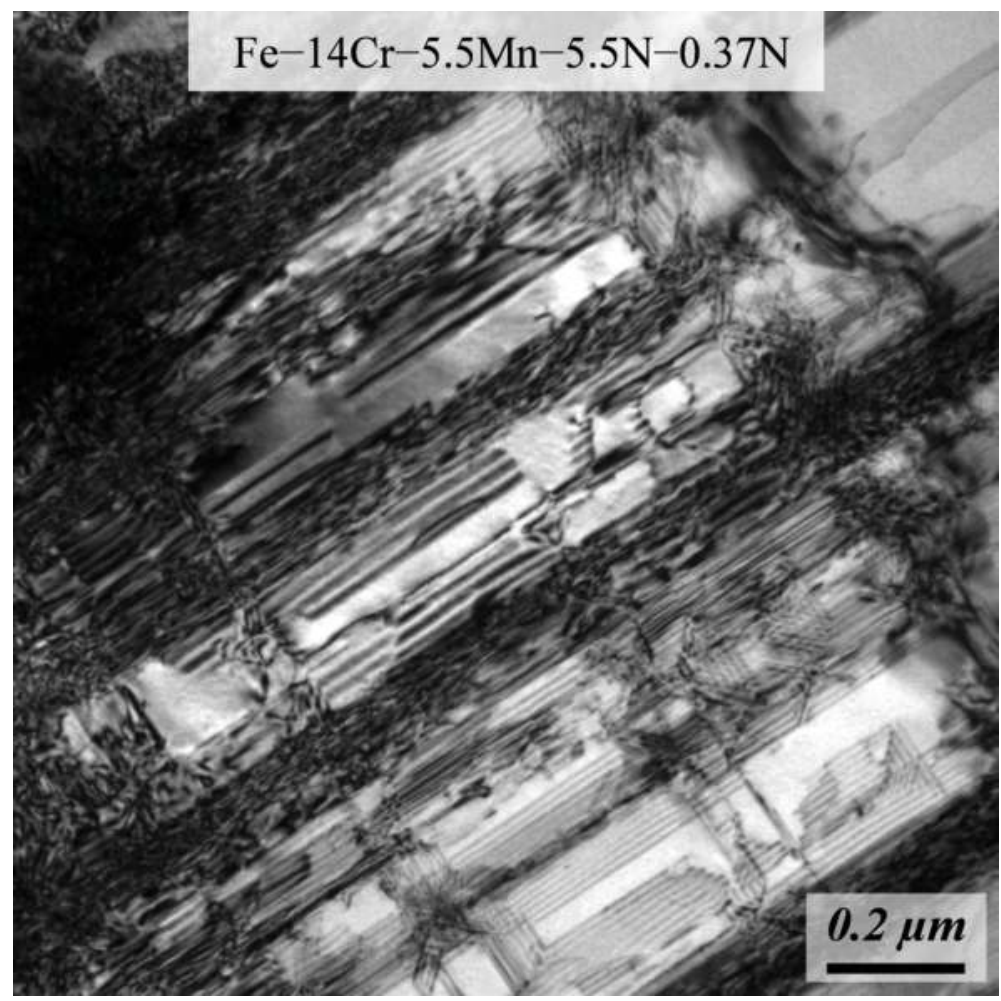

Figure 1. Stacking faults formed in an Fe- $14 \mathrm{Cr}-5.5 \mathrm{Mn}-5.5 \mathrm{Ni}-0.37 \mathrm{~N}$ steel after $64 \%$ tensile deformation at $-40^{\circ} \mathrm{C}$.

The schematic in Figure 4 summarizes the temperature dependence of deformation-induced microstructural changes in austenitic steels. The spectrum of processes shown in the schematic does not necessarily occur in all austenitic steels. Whether or not a given process is activated is decided by the alloy system. Highly stable austenitic steels may not exhibit the microstructural changes relying on very low SFEs. For example, the austenitic stainless steel Fe-18Cr-20Ni with a high stability does not experience deformation-induced $\alpha^{\prime}$-martensite formation even after the application of almost $100 \%$ tensile elongation at $-196^{\circ} \mathrm{C}[14,17]$. Furthermore, the tendency of an austenitic steel to form $\varepsilon$-martensite or twinning depends on the alloy chemistry. In high Mn steels, for instance, alloying with Si increases the likelihood of $\varepsilon$-martensite formation at the expense of deformation twinning [18]. Table 1 summarizes the types of deformation-induced microstructural changes (twinning and $\varepsilon$-martensite) in modifications of FeCrMnNi-based austenitic stainless steels. Some of the alloys listed in Table $\mathbf{1}$ are twinning only or $\varepsilon$-martensite only systems. Nevertheless, a majority of austenitic stainless steels are capable of exhibiting both the preceding deformation processes as byproducts of planar glide, caused by the ready dissociation of Shockley partial dislocations $[19,20]$. 


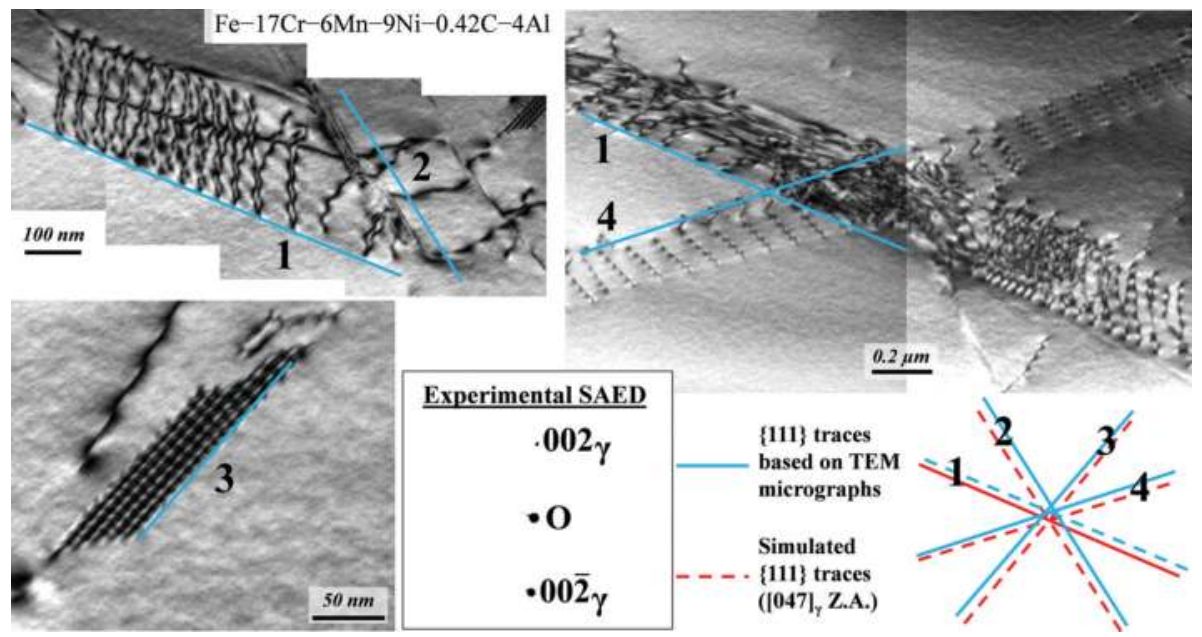

Figure 2. TEM micrographs and the corresponding selected-area electron diffraction (SAED) pattern of an Al-alloyed Fe-17Cr-6Mn-9Ni-0.42C-4Al steel after the application of nearly 4\% compressive strain at RT. The zone axis (Z.A.) of austenite cannot be determined from the recorded SAED pattern which only comprises two 002 diffraction spots. Instead, the angular relationships among the traces of $\{111\}_{\gamma}$ glide planes (superimposed solid lines), which may be identified by the glide plane features, allow to determine the zone axis (Z.A. $/ /<047>_{\gamma}$ ).

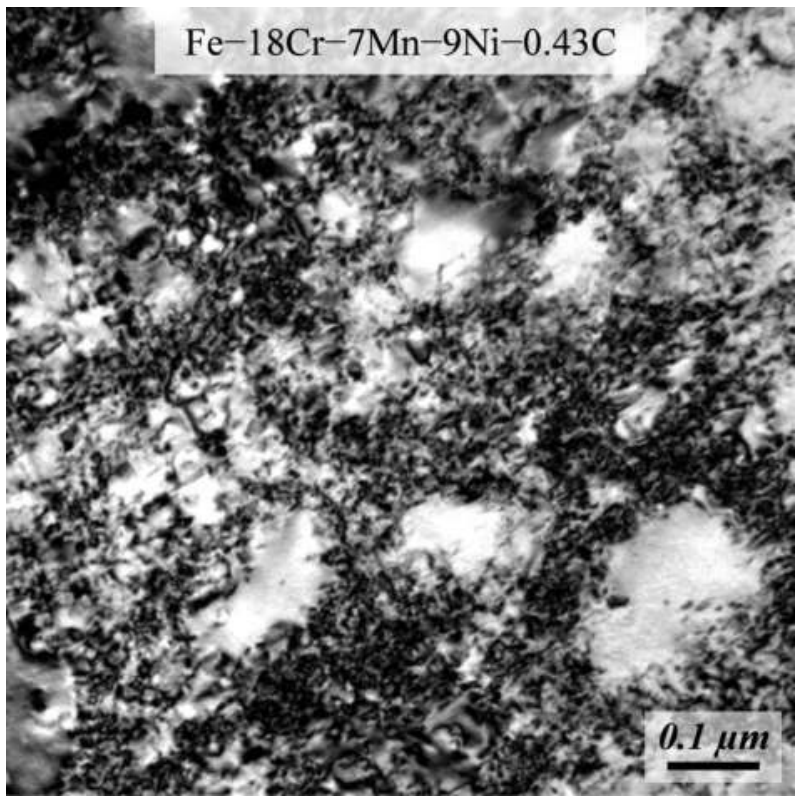

Figure 3. Microstructure of an Fe- $18 \mathrm{Cr}-7 \mathrm{Mn}-9 \mathrm{Ni}-0.43 \mathrm{C}$ steel after $45 \%$ tensile deformation at $200^{\circ} \mathrm{C}$. 


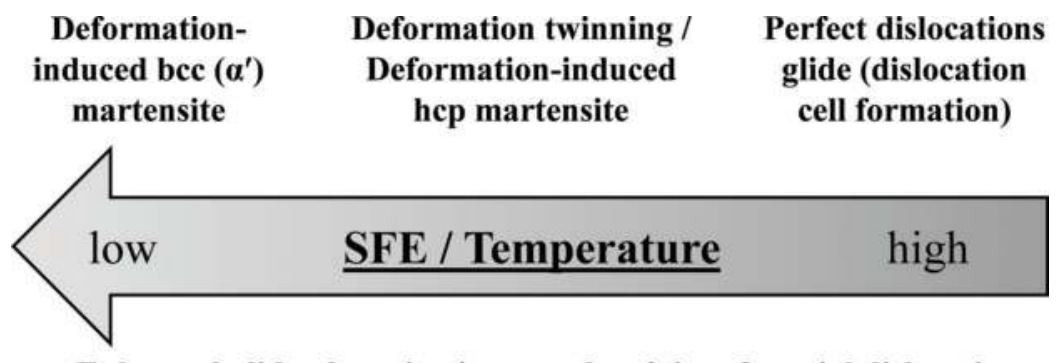

Enhanced glide planarity, increased activity of partial dislocations

Figure 4. Schematic representation of the effects of SFE and temperature on the microstructural changes in austenitic steels.

\begin{tabular}{lcc}
\hline Alloy & Twinning & $\varepsilon$-Martensite \\
\hline Fe-16Cr-(6-7)Mn-(6-9)Ni [21, 22] & $\checkmark$ & $\checkmark$ \\
Fe-(17-18)Cr-(6-7)Mn-9Ni-0.4C-(0 \& 4)Al [15] & $\checkmark$ & $\checkmark$ \\
Fe-14Cr-5.5Mn-5.5Ni-0.37N [14] & - & $\checkmark$ \\
Fe-15Cr-3Mn-3Ni-(0.05-0.25)C-(0.1-0.13)N [23, 24] & $\checkmark$ & $\checkmark$ \\
Fe-19Cr-3Mn-4Ni-(0.05-0.25)C-(0.1-0.13)N [25-27] & $\checkmark$ & - \\
Fe-15Cr-1Mo-0.3C-0.4N [28] & $\checkmark$ & $\checkmark$ \\
\hline
\end{tabular}

Table 1. Occurrence of twinning/ $\varepsilon$-martensite formation as a function of chemical composition (mass-\%).

Deformation at temperatures lower than those associated with $\varepsilon$-martensite formation and twinning leads to the formation of $\alpha^{\prime}$-martensite. As mentioned earlier, this does not apply to highly stable austenitic steels in which the threshold SFEs for the $\alpha^{\prime}$-martensite formation may not be attained even at cryogenic temperatures [14]. The $\alpha^{\prime}$-martensite formation under extremely planar glide conditions commonly occurs at the intersections of planar glide features [29-31]. Examples of deformation-induced $\alpha^{\prime}$-martensite formation in conjunction with planar glide features are shown in Figure 5. Even in cases where it is difficult to identify intersection of planar glide features, such as the example of Figure $5 \mathbf{d}$ where the $\alpha^{\prime}$-martensite appears to have formed in association with deformation twins, the activation of at least one conjugate partial dislocation glide system is quite likely. After all, the most widely accepted models proposed for the $\alpha^{\prime}$-martensite formation rely on the occurrence of two shears in directions compatible with the glide direction of partial dislocations [32-35]. The magnitudes of the shears needed to cause the lattice change to bcc/bct are only fractions of the full twinning shear. Even the formation of spontaneous $\alpha^{\prime}$-martensite appears to be a consequence of stacking fault interactions. As the microstructure of the Fe-15Cr-1Mo-0.3C-0.4N steel after partial transformation to athermal $\alpha^{\prime}$-martensite shows (Figure 6), a high density of stacking faults exists in the austenite, in particular in the immediate vicinity of the transformed regions. Therefore, further transformation of austenite most likely involves the spontaneous dissociation and interaction of the stacking faults. This suggests that the SFE must be extremely low at the $\alpha^{\prime}$-martensite start $\left(\mathrm{M}_{\mathrm{s}}\right)$ temperature. 

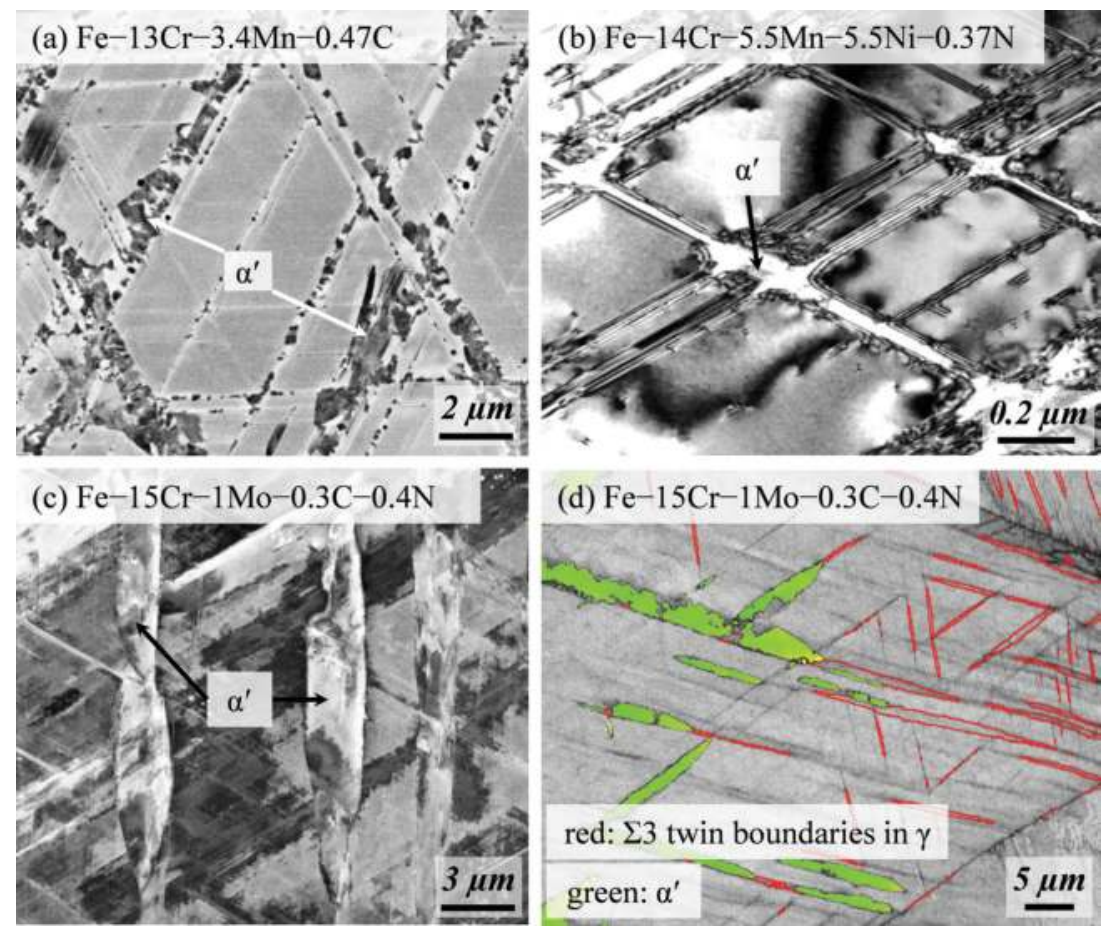

Figure 5. Examples of deformation-induced $\alpha^{\prime}$-martensite formation in high carbon (a), high nitrogen (b), and high carbon and nitrogen $(\mathrm{d})$ austenitic stainless steels.

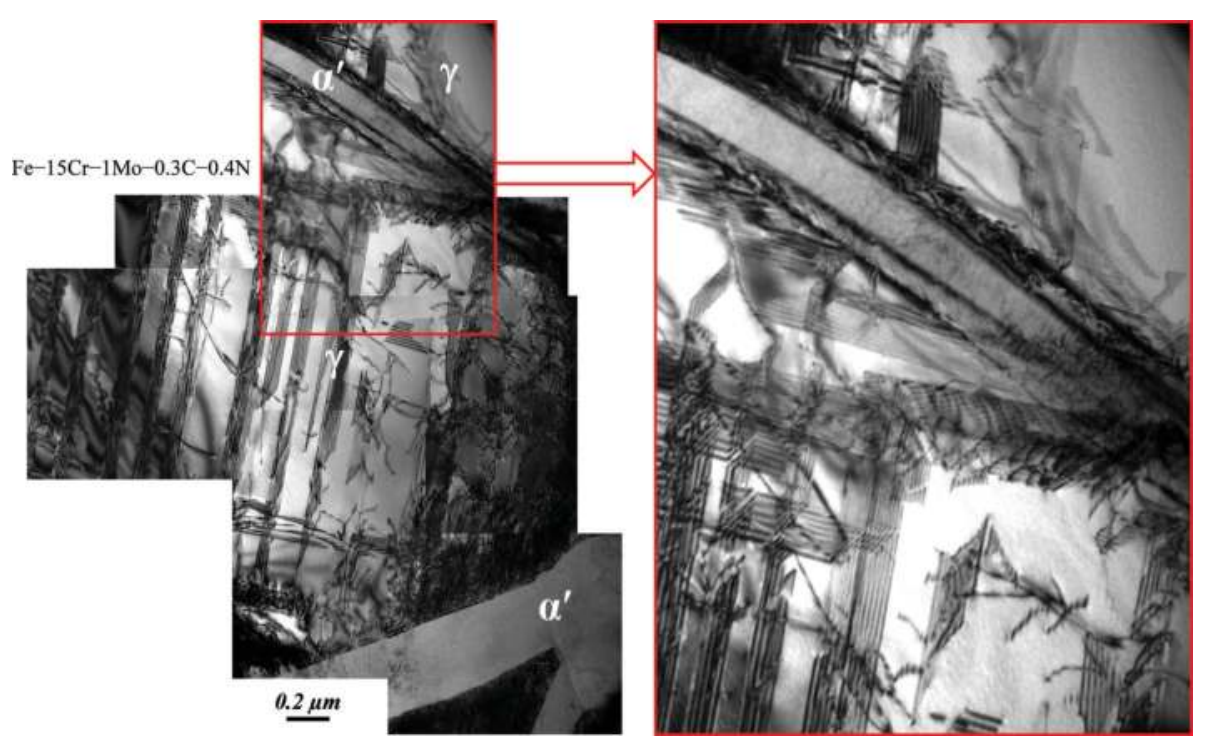

Figure 6. Microstructure of an Fe-15Cr-1Mo-0.3C-0.4N steel after partial transformation to spontaneous (athermal) $\alpha^{\prime}$-martensite by thermal treatment. 


\section{Influence of deformation-induced processes on the strain-hardening behavior and tensile elongation}

An important consequence of decreasing the tensile temperature of austenitic stainless steels is the increase in the strain-hardening rate. This is demonstrated using the true stress-strain and strain-hardening curves for an Fe-18Cr-20Ni steel (Figure 7) [17]. The enhancement of strain-hardening rate and its extended near-linear hardening at low temperatures can be explained by the decrease in the SFE and the increased activity of stacking faults. At $-196^{\circ} \mathrm{C}$, the strain-hardening rate remains almost constant until fracture. Near-linear strain hardening during tensile deformation is the characteristic of many austenitic stainless steels at temperatures where SFE is sufficiently low to ensure a high glide planarity but not low enough to enable the formation of $\alpha^{\prime}$-martensite. Figure 8 shows the true strain-hardening curves for an $\mathrm{Fe}-16 \mathrm{Cr}-8 \mathrm{Mn}-7 \mathrm{Ni}$-1Si steel deformed at various temperatures [36]. At temperatures below $\mathrm{M}_{\mathrm{d}}{ }^{\gamma} \rightarrow{ }^{\alpha^{\prime}}$ temperature which is between 20 and $60^{\circ} \mathrm{C}$, the increase in the work-hardening rate characteristic of deformation-induced $\alpha^{\prime}$-martensite formation can be readily identified [37]. The strain-hardening curves indicate that near-linear strain hardening in austenitic steels is achieved at temperatures near $\mathrm{M}_{\mathrm{d}}{ }^{\gamma} \rightarrow{ }^{\alpha^{\prime}}$ temperature [15].

The schematic in Figure 9 generalizes the temperature dependence of tensile elongation in austenitic stainless steels $[10,15,38-43]$. The schematic elongation curve consists of three regions marked I-III. In region I, the elongation shows a weak temperature dependence which resembles that of materials with wavy glide, for example, ferritic steels. The region marked II is characterized by enhanced low-temperature ductility due to the enhanced glide planarity. The enhancement of ductility by lowering temperature in region II is usually attributed to deformation-induced microstructural changes such as $\varepsilon$-martensite transformation, the $\varepsilon$-TRIP effect [44], and deformation twinning, the TWIP effect [38]. The hcp stacking of close-packed planes in $\varepsilon$-martensite may be achieved by the glide of $1 / 6<112>$ Shockley partials on every second $\{111\}$ plane [45]. Deformation twins, on the other hand, can occur by the glide of $1 / 6<112>$ Shockley partials on successive $\{111\}$ planes [46, 47]. The region marked III in Figure 9 can appear at deformation temperatures below $\mathrm{M}_{\mathrm{d}}{ }^{\gamma} \rightarrow{ }^{\alpha^{\prime}}$ temperature. The temperature-dependent true stress-strain curves in Figures $\mathbf{1 0}(\mathbf{a}, \mathbf{b})$ and the associated $\alpha^{\prime}$-martensite fractions at the end of tensile tests
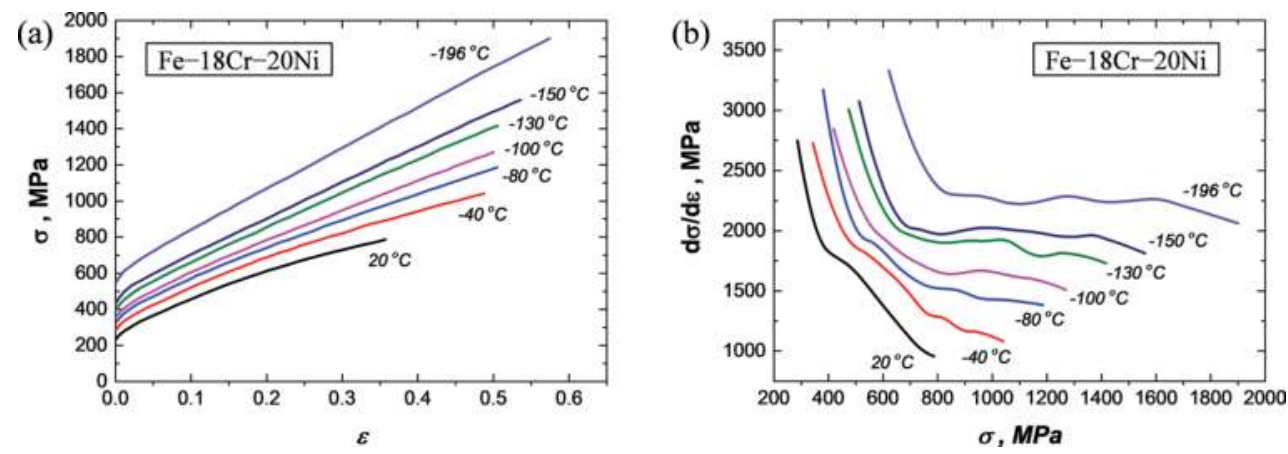

Figure 7. (a) Temperature dependence of true stress-strain curves for an Fe-18Cr-20Ni steel; (b) true strain-hardening curves corresponding to (a) (adapted from Ref. [17]). 


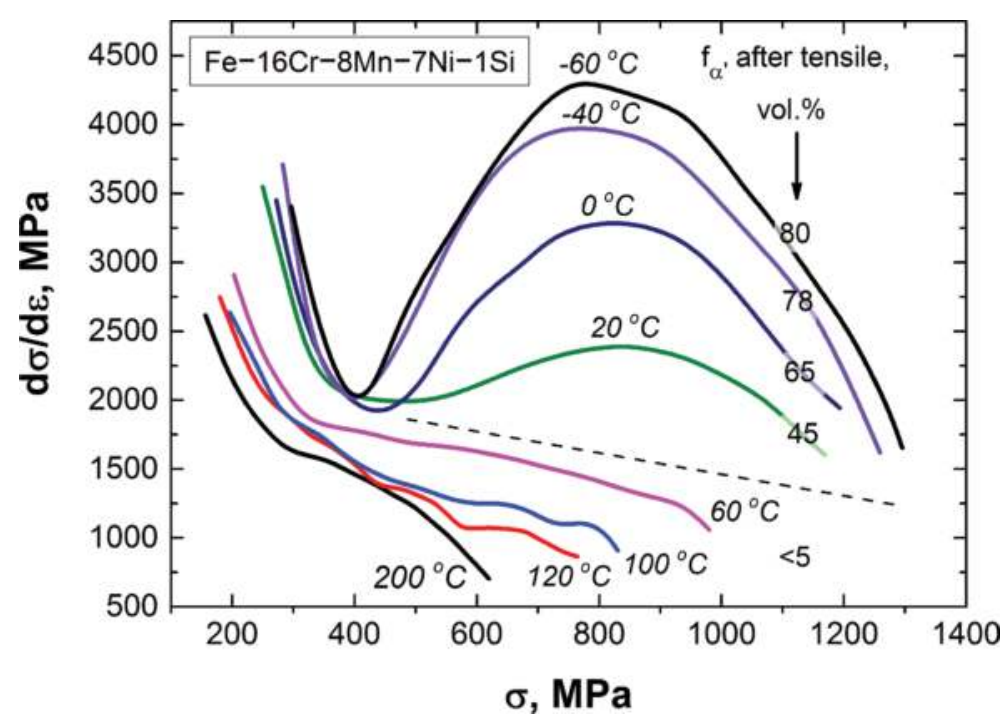

Figure 8. Temperature dependence of true strain-hardening curves for an Fe-16Cr-8Mn-7Ni-1Si steel. The martensite fractions after tensile tests are also marked (adapted from Ref. [36]).

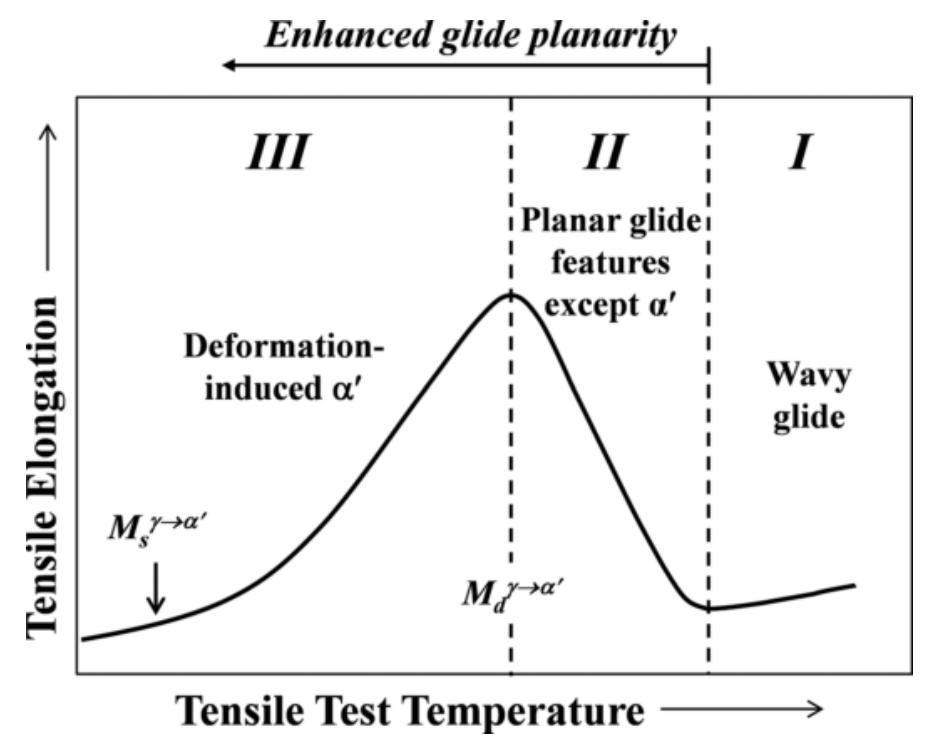

Figure 9. Generalized temperature dependence of tensile elongation in austenitic steels.

[36] (Figure 10c) confirm the negative impact of deformation-induced $\alpha^{\prime}$-martensite formation on the tensile ductility. Accordingly, the region III of elongation curves is absent in highly stable austenitic steels which do not undergo deformation-induced $\alpha^{\prime}$-martensite formation (e.g., the Fe-18Cr-20Ni alloy in Figure 7). The loss of ductility in region III in spite of the enhanced 

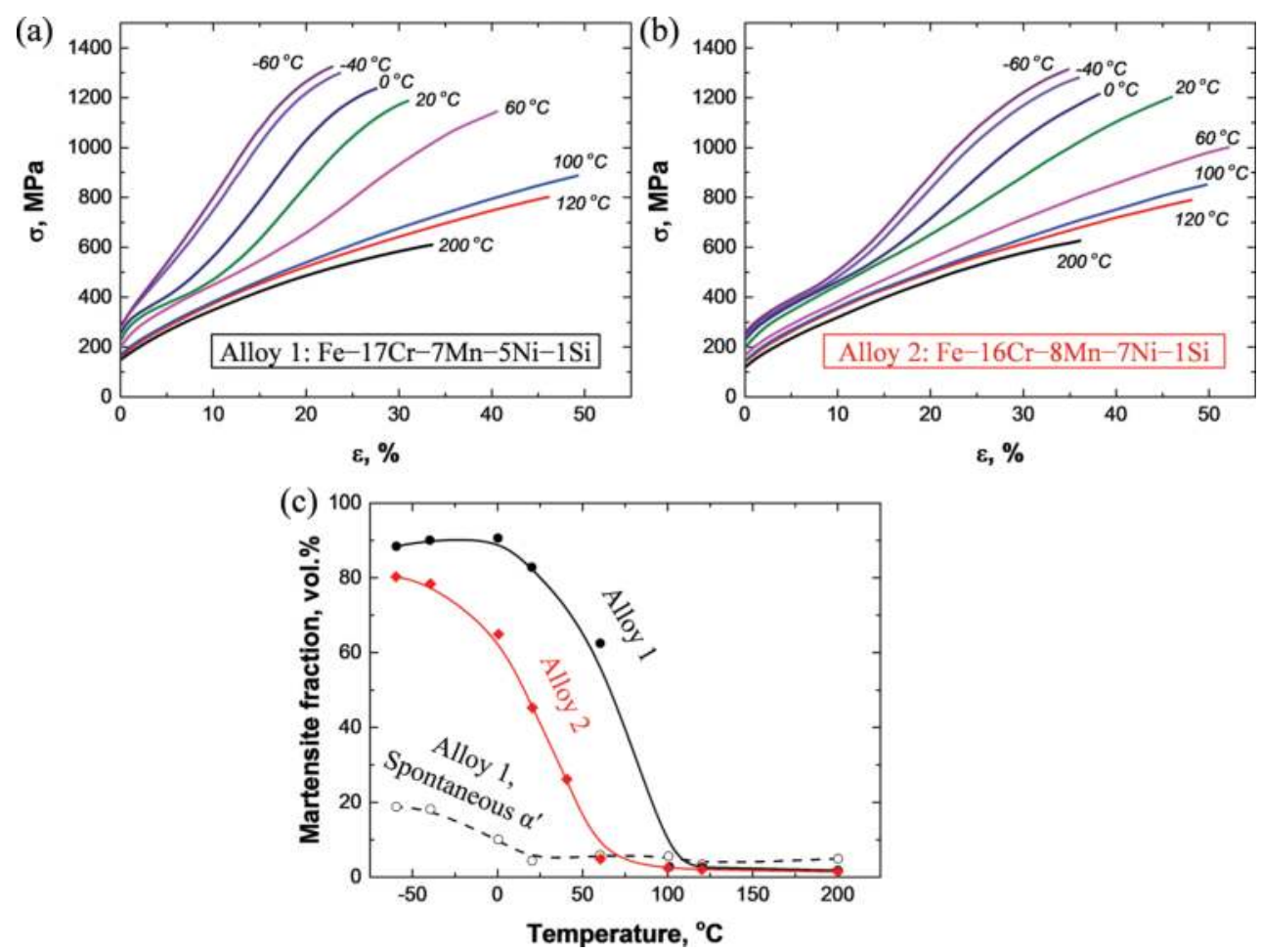

Figure 10. (a and b) Temperature dependence of true stress-strain curves for the marked steel compositions; (c) deformation-induced martensite fractions after tensile tests. The spontaneous martensite fractions are also given for alloy 1 (adapted from Ref. [36]).

glide planarity of austenite is due to the gradual replacement of austenite by the less ductile $\alpha^{\prime}$-martensite.

Although the proximity of $\mathrm{M}_{\mathrm{d}}{ }^{\gamma} \rightarrow{ }^{\alpha^{\prime}}$ temperature and the temperature associated with maximum tensile elongation has been documented in many researches involving tensile tests at various temperatures followed by the quantification of bulk $\alpha^{\prime}$-martensite fractions in the uniformly strained regions of tensile specimens [14, 17, 36-39], there also exist experimental results in support of the ductility-enhancing effect of $\alpha^{\prime}$-martensite formation [10, 14]. Figure 11 shows such an instance where the tensile elongation increases concurrently with the formation of $\alpha^{\prime}$ at temperatures below $\mathrm{M}_{\mathrm{d}}{ }^{\gamma} \rightarrow{ }^{\alpha^{\prime}}$ temperature. This observation has been justified by the non-uniform distribution of alloying elements, originating from the solidification step [14]. During solidification, alloying elements tend to segregate from the dendrite cores into the surrounding liquid, namely interdendritic regions in the final microstructure [48] (Figure 12). The severity of segregation depends mainly on the cooling rate during solidification. Nevertheless, the solidification mode (austenitic/ferritic) should also be relevant to the extent of solidification segregation. The compositional difference between the dendritic and interdendritic regions could lead to the inhomogeneity of material parameters such as SFE and $\mathrm{M}_{\mathrm{d}}{ }^{\gamma} \rightarrow{ }^{\alpha^{\prime}}$ temperature. Upon plastic deformation, the dendritic and interdendritic regions will exhibit deformation-induced processes commensurate with 


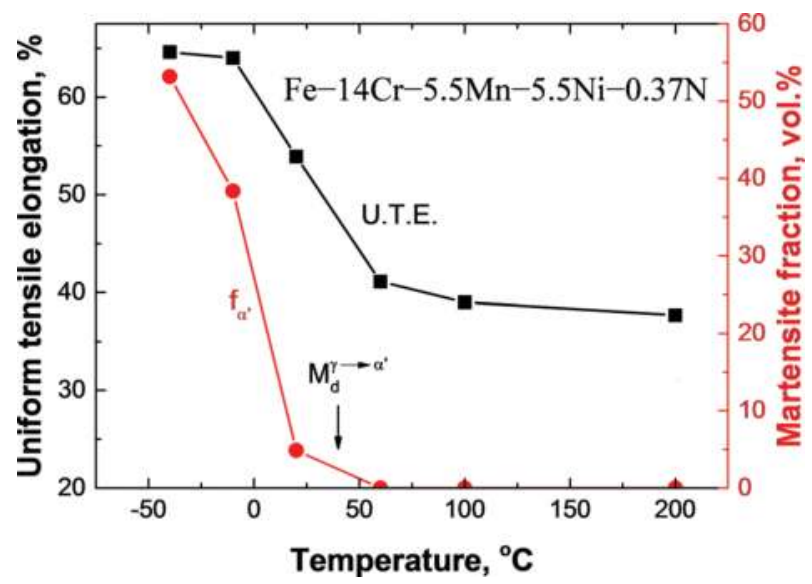

Figure 11. Temperature dependence of uniform tensile elongation for an Fe-14Cr-5.5Mn-5.5Ni-0.37N steel and the associated deformation-induced martensite fractions (adapted from Ref. [14]).

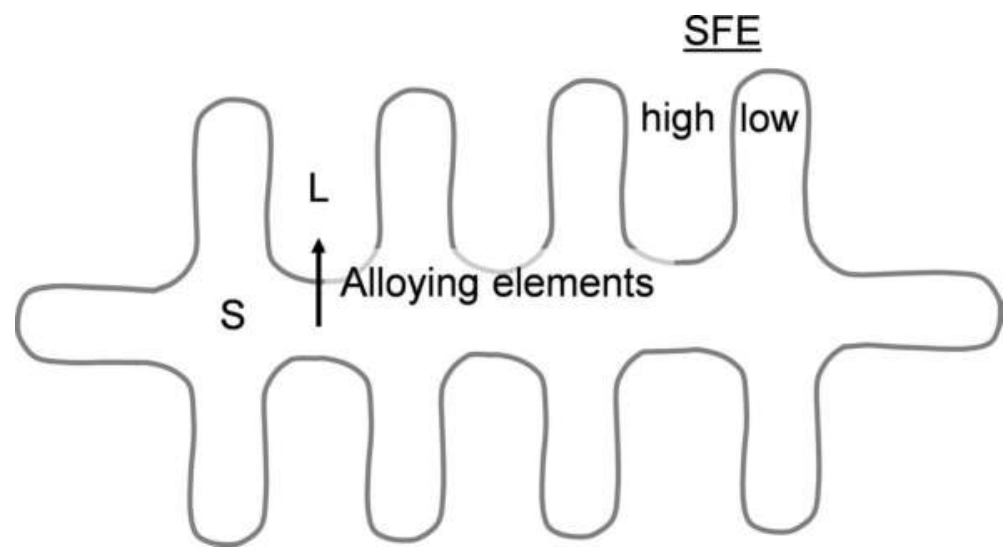

Figure 12. Schematic representation of the segregation of alloying element during solidification. The solid (S) and liquid (L) regions will appear as dendritic and interdendritic regions with different SFE values in the final microstructure.

their SFE [49]. For instance, the dendritic regions with a leaner chemical composition and a lower SFE compared to the interdendritic regions will exhibit a higher glide planarity. In other words, as the deformation temperature decreases, the formation of stacking fault, twins/ $\varepsilon$-martensite, and $\alpha^{\prime}$ is first triggered in the dendritic regions [14]. The presence of a gradient of chemical composition in the microstructure might be responsible for the reported plasticity-enhancing effect of $\alpha^{\prime}$-martensite formation, the so-called TRIP effect. To visualize how the inhomogeneity of chemical composition can mask the negative impact of deformation-induced $\alpha^{\prime}$-martensite formation on the tensile elongation, the temperature dependence of tensile elongation and deformationinduced $\alpha^{\prime}$-martensite fractions for two steels with slight differences in the chemical composition are summarized in Figure 13 [36]. The steels Fe-16Cr-7Mn-6Ni-1Si and Fe-16Cr-8Mn-7Ni-1Si can 


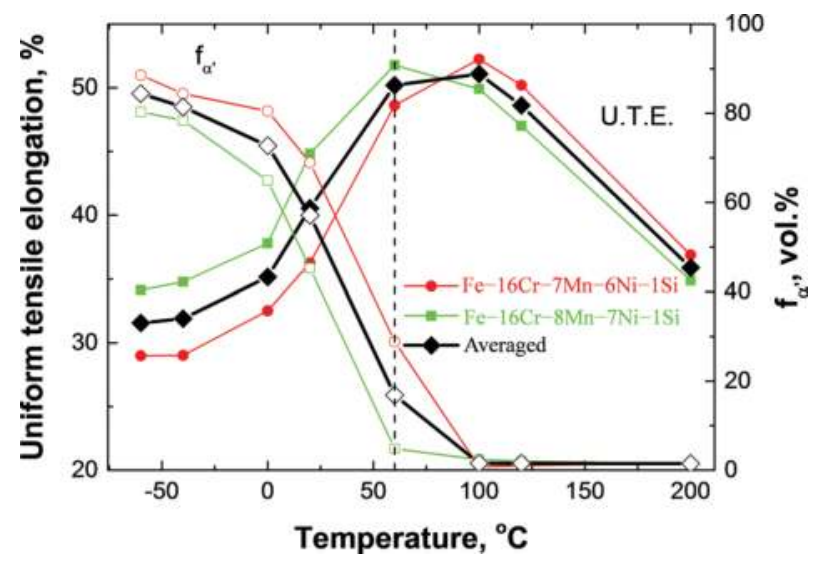

Figure 13. Temperature dependence of uniform tensile elongation for two steels with slightly different chemical compositions and the averaged values (adapted from Ref. [36]).

represent the chemical compositions of dendritic and interdendritic regions of segregated steel, respectively. The tensile elongation of a hypothetical alloy consisting of equal fractions of these two steels is estimated in Figure $\mathbf{1 3}$ by averaging (rule of mixtures). The rule of mixtures was also applied to determine the temperature dependence of deformation-induced $\alpha$-martensite fraction in the hypothetical alloy. As the dashed line in Figure $\mathbf{1 3}$ shows, the tensile elongation of the segregated hypothetical alloy is not much impaired by the formation of approximately $17 \mathrm{vol} . \%$ deformation-induced $\alpha^{\prime}$-martensite. In the presence of still larger gradients of chemical composition, the tensile ductility might even increase in spite of the formation of $\alpha^{\prime}$-martensite in the least stable regions of the microstructure. This can indeed take place if the negative impact of $\alpha^{\prime}$-martensite formation in the less stable regions of the microstructure is more than neutralized by the positive effect of planar glide enhancement in the more stable regions of the microstructure [14]. Based on the preceding discussion, the recognition of the $\alpha^{\prime}$-martensite formation as a plasticity-enhancing mechanism ( $\alpha$ '-TRIP effect) in TRIP-assisted [50] and quenched and partitioned (Q\&P) [51] steels containing small quantities of austenite is possibly due to local variations in the chemical composition of austenite.

\section{Design of austenitic stainless steels}

As shown in the schematic of Figure 9, highest tensile elongations for austenitic steels with a uniform distribution of alloying elements may be obtained over a narrow temperature range near $\mathrm{M}_{\mathrm{d}}^{\gamma} \rightarrow{ }^{\alpha^{\prime}}$ temperature. The objective of many austenitic steel developments is therefore to ensure that the deformation temperature or the service temperature, where a high formability or a high-energy absorption capacity is required, lies in the vicinity of the peak elongation temperature. It is because of formability considerations that the $\mathrm{M}_{\mathrm{d}}{ }^{\gamma} \rightarrow^{\alpha^{\prime}}$ temperature of commercial austenitic stainless steels is often in the vicinity of room temperature [52, 53]. Therefore, the $\mathrm{M}_{\mathrm{d}}{ }^{\gamma} \rightarrow^{\alpha^{\prime}}$ temperature may be used to predict the influence of alloying elements on the 
elongation curve. Tensile tests at various temperatures of austenitic stainless steels with varied amounts of $\mathrm{Ni}[39,42], \mathrm{Mn}[43], \mathrm{Al}[15], \mathrm{Cr}$ [23, 25, 27], C [23, 24], and N [25] have confirmed that they shift the peak elongation temperature to lower temperatures. All of the preceding alloying elements except $\mathrm{Al}$ are unanimously known to decrease both $\mathrm{M}_{\mathrm{d}}{ }^{\gamma} \rightarrow{ }^{\alpha^{\prime}}$ and $\mathrm{M}_{\mathrm{s}}$ temperatures [54,55]. The formation of AlN and the associated reduction in the solute $\mathrm{N}$ content might be responsible for the reported increase in the $\mathrm{M}_{\mathrm{s}}$ temperature upon the addition of only small quantities of $\mathrm{Al}$. This effect is expected to disappear when $\mathrm{Al}$ is present in quantities much higher than the stoichiometric Al content needed for the full stabilization of solute N. For instance, the addition of 4.9 mass- $\% A l$ to a cast iron has decreased the $\mathrm{M}_{\mathrm{s}}$ temperature [56].

Economical design of highly formable austenitic stainless steels, namely lean austenitic stainless steel compositions, should be based on the principle that all of the elements which decrease the $\mathrm{M}_{\mathrm{d}}{ }^{\gamma} \rightarrow^{\alpha^{\prime}}$ temperature, irrespective of their reported influence on the SFE, also decrease the peak elongation temperature. This is shown schematically in Figure 14. To secure a high formability at room temperature, the $\mathrm{M}_{\mathrm{d}}{ }^{\gamma} \rightarrow{ }^{\alpha^{\prime}}$ temperature must be close to room temperature as is the case with commercial austenitic stainless steels such as the AISI 304-grade (Fe-18Cr-10Ni) stainless steel. The development of the AISI 200 series (FeCrNiMn) austenitic stainless steels in which $\mathrm{Ni}$ is partially replaced with $\mathrm{Mn}$ is also in accord with the preceding design principle [39].

Since $\mathrm{C}$ and $\mathrm{N}$ effectively decrease the $\mathrm{M}_{\mathrm{d}}{ }^{\gamma} \rightarrow{ }^{\alpha^{\prime}}$ temperature, an economical design approach would be to partially replace the substitutional alloying elements $\mathrm{Cr}, \mathrm{Ni}$, and $\mathrm{Mn}$ with the interstitials $\mathrm{C}$ and $\mathrm{N}$. The maximum level of $\mathrm{N}$, which can be introduced into the molten steel, depends on both the chemistry and the $\mathrm{N}_{2}$ partial pressure applied during casting and melting [57]. Stainless steel compositions Fe-15Cr-3Mn-3Ni-0.1N-(0.05-0.25)C exemplify the efforts made to reduce the substitutionals content by the addition of both $\mathrm{C}$ and $\mathrm{N}[23,24]$. Nevertheless, even for the alloy containing the highest $C$ content of 0.25 mass- $\%$, the stability

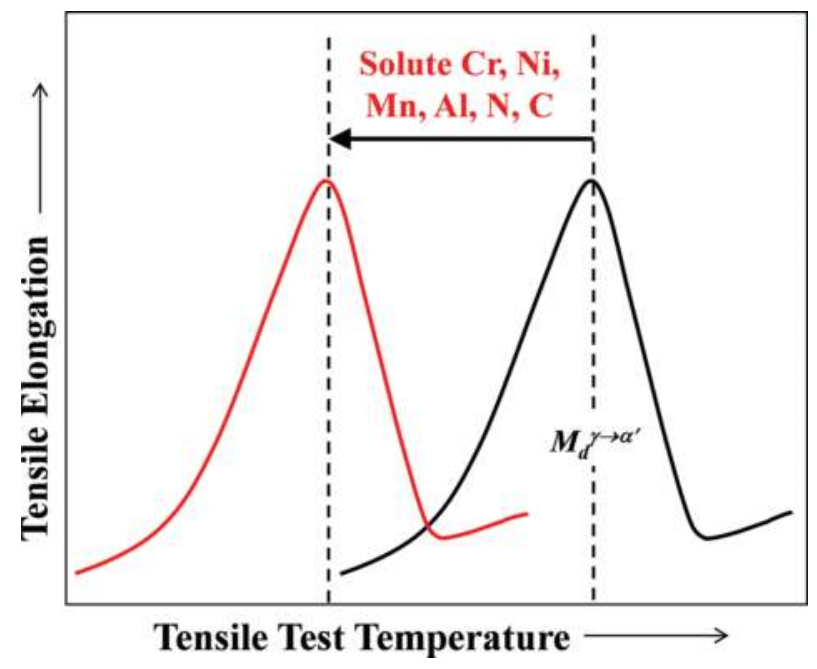

Figure 14. Influence of alloying elements on the temperature dependence of tensile elongation. 
of austenite at room temperature was not sufficiently high to suppress the early deformationinduced occurrence of $\alpha^{\prime}$-martensite. As a result, the room temperature tensile elongation remained below $15 \%$. At $200^{\circ} \mathrm{C}$, where the deformation-induced $\alpha^{\prime}$-martensite formation was inhibited, the total elongation increased to about $65 \%$. In comparison, the Fe-19Cr-4Ni-3Mn$0.15 \mathrm{~N}-(0.05-0.25) \mathrm{C}$ steels with higher $\mathrm{Cr}, \mathrm{Ni}$, and $\mathrm{N}$ contents exhibited tensile elongations up to $50 \%$ at room temperature [25].

As long as the full dissolution of carbides and nitrides is enabled, still higher quantities of interstitials may be added to stainless steels to reduce the required amounts of substitutional

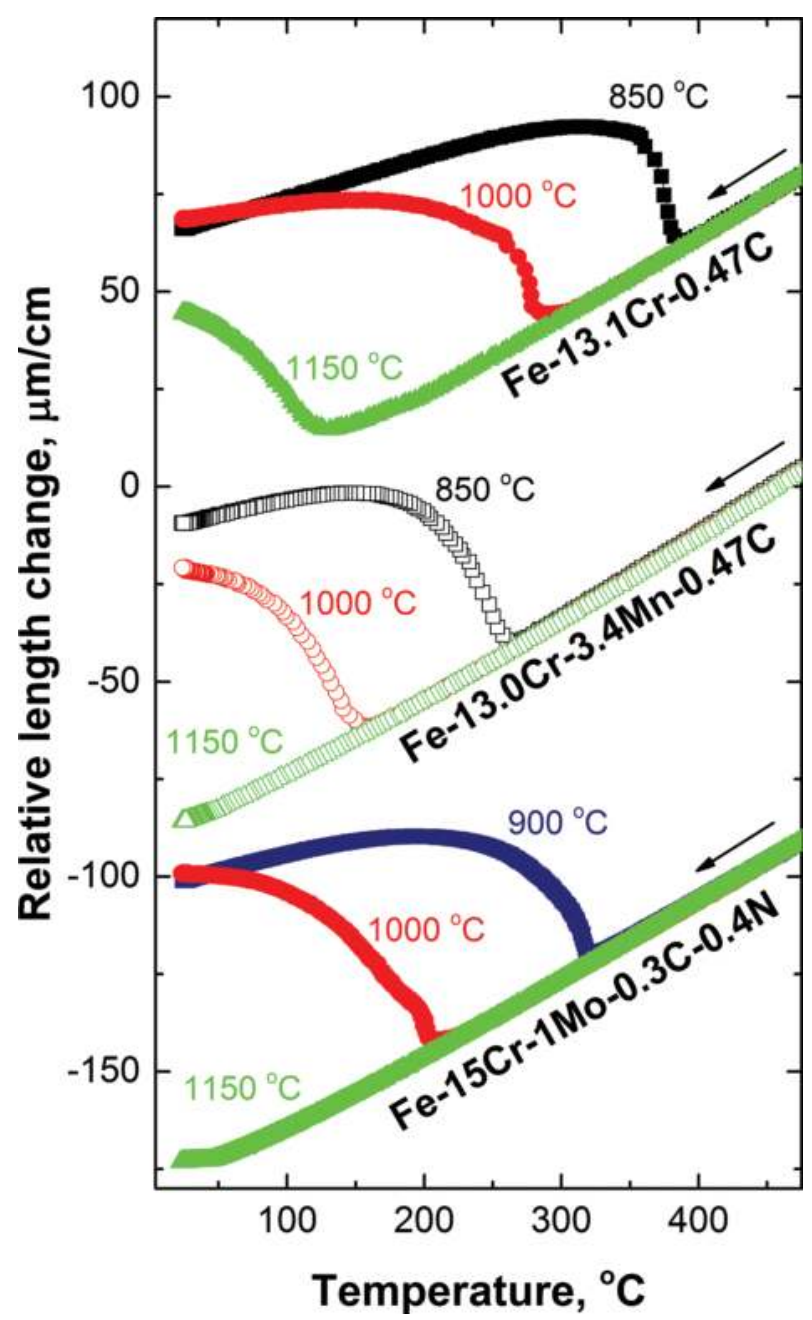

Figure 15. Relative length changes during cooling of Fe-13.1Cr-0.47C, Fe-13.0Cr-3.4Mn-0.47C, and Fe-15Cr-1Mo- $0.3 \mathrm{C}-0.4 \mathrm{~N}$ steels from the indicated solution-annealing temperatures. As the solution-annealing temperature increases, the $\mathrm{M}_{\mathrm{s}}$ temperature shifts to lower temperatures. 
alloying elements. Interstitial alloying elements are also effective solid solution strengtheners of austenite. Fe-18Cr-10Mn-base steels alloyed with up to 0.69 mass-\% $\mathrm{N}$ are examples of $\mathrm{N}$-alloyed stainless steels free of $\mathrm{Cr}_{2} \mathrm{~N}$ precipitates at the solution-annealing temperature [58, 59]. Alloying with higher amounts of $N$ or very high levels of $(C+N)$ will increase the solution-annealing temperature needed for the full dissolution of carbides and nitrides. On this basis, the complete dissolution of carbides and nitrides in the stainless steel Fe-19Cr-19Mn-0.49C-0.58N [60] appears improbable. In fact, the presence of $\mathrm{Cr}$-rich carbides and nitrides is not desirable since $\mathrm{Cr}, \mathrm{C}$, and $\mathrm{N}$ will then not contribute to the stabilization of austenite. Furthermore, the corrosion resistance is impaired by the presence of $\mathrm{Cr}$-rich precipitates. Assuming that all interstitials in an alloy such as the Fe-19Cr-19Mn-0.49C-0.58N steel are taken into solution by a high-temperature solution-annealing treatment, the $\mathrm{M}_{\mathrm{d}}{ }^{\gamma} \rightarrow{ }^{\alpha^{\prime}}$ temperature and the peak elongation temperature will be far lower than room temperature.

An alternative approach to the design of lean-alloy austenitic stainless steels is to modify the chemical composition and/or the thermal processing of standard quenched and tempered martensitic stainless steels to make them fully austenitic at room temperature. The room temperature microstructure of an Fe-13.1Cr- $0.47 \mathrm{C}$ steel after solution annealing at $1250^{\circ} \mathrm{C}$ consisted of $44 \mathrm{vol} . \% \alpha^{\prime}$-martensite and $56 \mathrm{vol} \% \%$ austenite. As shown in the dilatometry curves of Figure 15, the addition of 3.4 mass- $\% \mathrm{Mn}$ to the alloy decreased the $\mathrm{M}_{\mathrm{s}}$ temperature to around room temperature such that a fully austenitic microstructure was obtained. $\mathrm{M}_{\mathrm{d}}{ }^{\gamma} \rightarrow^{\alpha^{\prime}}$ temperature for the latter Mn-added steel is much higher than room temperature. Accordingly, significant enhancement of tensile ductility was observed at $200^{\circ} \mathrm{C}$ (Figure 16). A similar scenario arises in the case of steels containing both $\mathrm{C}$ and $\mathrm{N}$, for instance the commercial Fe-15Cr-1Mo-0.4N-0.3C steel which is conventionally used in the martensitic condition [28]. After solution annealing at $1250^{\circ} \mathrm{C}$ which resulted in a fully austenitic microstructure, ten-

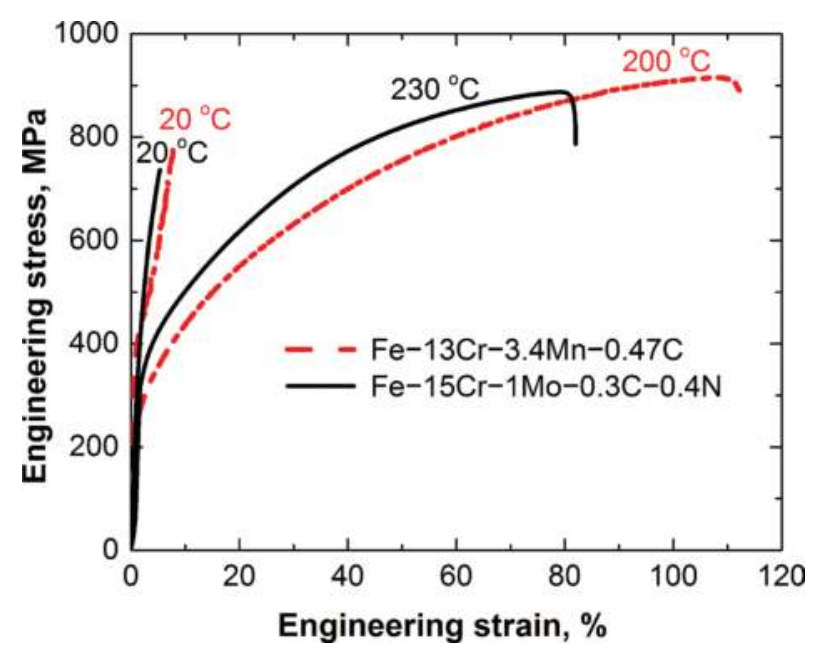

Figure 16. Engineering stress-strain curves for Fe-13Cr-3.4Mn-0.47C (dashed lines) and Fe-15Cr-1Mo-0.4N-0.3C (solid lines) steels at the indicated temperatures (adapted from [28, 61]). 
sile elongation at room temperature was less than $5 \%$. Tensile elongation was increased to $80 \%$ at $230^{\circ} \mathrm{C}$ (Figure 16). Such lean austenitic stainless steel compositions may be used for warm-forming operations at temperatures around $200^{\circ} \mathrm{C}$. In the case of both Fe-13Cr-3.4Mn0.47C and Fe-15Cr-1Mo-0.4N-0.3C stainless steels, decreasing the $\mathrm{M}_{\mathrm{d}}{ }^{\gamma} \rightarrow{ }^{\alpha^{\prime}}$ temperature to room temperature by raising the substitutionals content would be a possible way to enhance the room temperature tensile ductility.

\section{Challenges associated with the processing of high-interstitial steels}

The micrographs in Figure 17 show that the complete dissolution of high levels of $\mathrm{C}$ and $\mathrm{N}$ such as those contained in the Fe- $15 \mathrm{Cr}-1 \mathrm{Mo}-0.4 \mathrm{~N}-0.3 \mathrm{C}$ alloy requires the use of high solutionannealing temperatures. In the presence of precipitates, a higher amount of substitutional alloying elements will be required to ensure a sufficiently low $\mathrm{M}_{\mathrm{d}}{ }^{\gamma} \rightarrow^{\alpha^{\prime}}$ temperature. Furthermore,

\section{$\mathrm{Fe}-15 \mathrm{Cr}-1 \mathrm{Mo}-0.3 \mathrm{C}-0.4 \mathrm{~N}$}

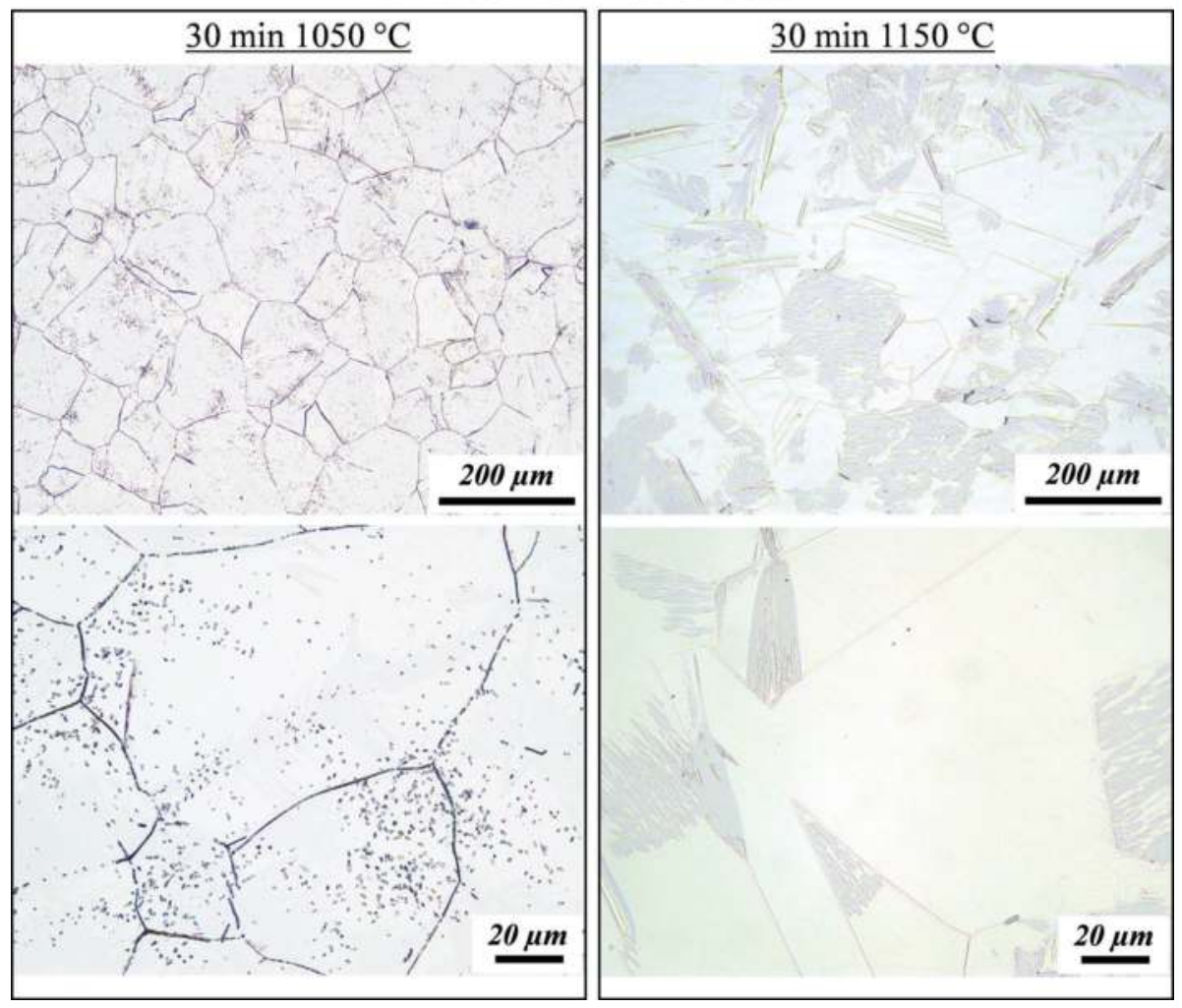

Figure 17. Optical micrographs of Fe-15Cr-1Mo-0.4N-0.3C steel after the indicated solution-annealing treatments. Oxalic acid was used as etchant. 


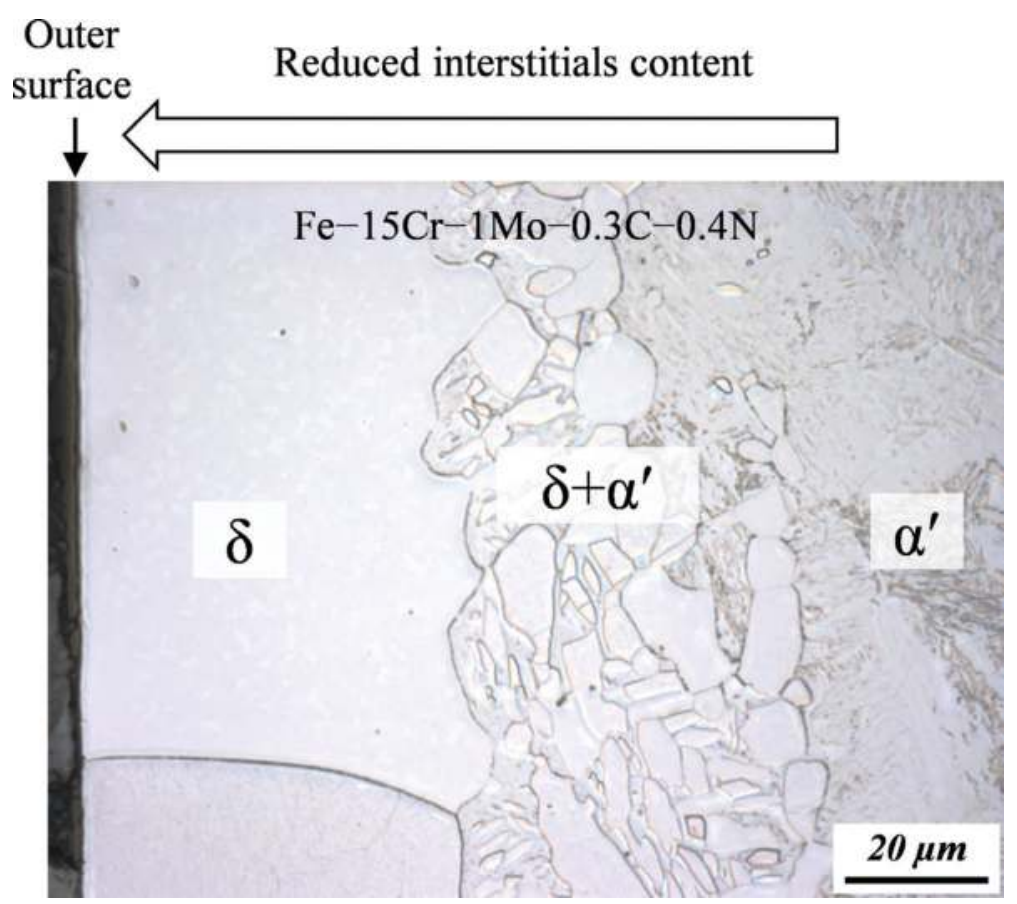

Figure 18. Optical micrograph of a section near the exposed surface of a dilatometry specimen of Fe- $15 \mathrm{Cr}-1 \mathrm{Mo}-0.4 \mathrm{~N}-0.3 \mathrm{C}$ steel after 13 heat treatment cycles at temperatures between 900 and $1180^{\circ} \mathrm{C}$. V2A reagent was used as etchant.

the presence of $\mathrm{Cr}$-rich carbides, nitrides, and carbo-nitrides such as $\mathrm{M}_{23} \mathrm{C}_{6}, \mathrm{M}_{7} \mathrm{C}_{3^{\prime}}$ and $\mathrm{M}_{2} \mathrm{~N}$ ( $\mathrm{M}$ denotes mainly $\mathrm{Cr}$ and $\mathrm{Fe}$ ) will deteriorate the corrosion resistance of stainless steels. The inevitable use of high solution-annealing temperatures increases the risk of decarburization, denitriding, and other surface problems such as uniform and intergranular types of oxidation. The loss of $\mathrm{C}$ and $\mathrm{N}$ near the surface will lead to a microstructure gradient from the surface toward inner regions. Commonly, a martensitic microstructure forms near the surface where the interstitials content is lowest $[23,28]$. In cases where the ferrite potential of the alloy in the absence of interstitials is high, even delta ferrite might form near the surface (Figure 18). Surface-to-bulk micro hardness profile measurements can be used to determine the depth of decarburization/denitriding [23, 28].

\section{Concluding remarks}

The occurrence of various deformation-induced processes such as perfect dislocations glide, deformation twinning, and deformation-induced $\varepsilon / \alpha^{\prime}$-martensite formation mechanisms in austenitic steels is governed by the SFE. As long as the SFE is known, it should be possible to decide which deformation-induced mechanism is activated during deformation. The SFE determination by experimental diffraction-based techniques (including TEM) is a time-consuming task 
and requires careful specimen preparation. Therefore, it would be useful to correlate SFE with material parameters which can be determined more readily and are less sensitive to artifacts arising from the specimen preparation. One such material parameter is the $\mathrm{M}_{\mathrm{d}}{ }^{\gamma} \rightarrow{ }^{\alpha^{\prime}}$ temperature which can be determined by tensile tests at various temperatures followed by the verification of $\alpha^{\prime}$-martensite formation for instance by magnetic measurements. The likelihood of a correlation between SFE and $\mathrm{M}_{\mathrm{d}}{ }^{\gamma} \rightarrow{ }^{\alpha^{\prime}}$ temperature can be visualized by recalling that the formation of $\alpha^{\prime}$-martensite is only enabled if the SFE is sufficiently low to enable the deformation-induced reaction of partial dislocations on intersecting $\{111\}_{\gamma}$ planes which is a requirement for the fcc $\rightarrow$ bcc transformation. Therefore, the influence of alloying elements on the SFE of austenitic stainless steels can be deduced from their influence on the $\mathrm{M}_{\mathrm{d}}{ }^{\gamma} \rightarrow^{\alpha^{\prime}}$ temperature. In contrast to the coefficients of alloying elements in the empirical equations proposed for the SFE estimation which are subject to a large scatter, the coefficients of alloying elements in the empirical relationships for the estimation of $\mathrm{M}_{\mathrm{d}}{ }^{\gamma} \rightarrow{ }^{\alpha^{\prime}}$ temperature are fairly consistent. Therefore, relationships giving the compositional dependence of $\mathrm{M}_{\mathrm{d}}{ }^{\gamma} \rightarrow{ }^{\alpha^{\prime}}$ temperature can be used as guidelines for the economical design of austenitic stainless steels. Due to the high efficiency of $\mathrm{C}$ and $\mathrm{N}$ in increasing the stability of austenite, they can be used to obtain austenite with an appropriate stability. The high temperatures required for the dissolution of carbides, nitrides, and carbo-nitrides and the tendency of $\mathrm{C}$ and $\mathrm{N}$ to escape from free surfaces are some of the challenges associated with the processing of high-interstitial stainless steels compared to that of conventional stainless steels.

\section{Acknowledgements}

The financial support of the German Research Foundation (Deutsche Forschungsgemeinschaft, DFG) in the framework of the Collaborative Research Center 799 (CRC799) and the research grants MO 2580/1-1 and MO 2580/2-1 is gratefully acknowledged. Thanks are also due to the scientific and technical staff involved in the above projects.

\section{Author details}

Javad Mola

Address all correspondence to: javad.mola@iest.tu-freiberg.de

Institute of Iron and Steel Technology, Technische Universität Bergakademie Freiberg, Freiberg, Germany

\section{References}

[1] Allain S, Chateau J-P, Bouaziz O, Migot S, Guelton N. Correlations between the calculated stacking fault energy and the plasticity mechanisms in Fe-Mn-C alloys. Materials Science and Engineering A. 2004;387-389:158-162. DOI: 10.1016/j.msea.2004.01.059 
[2] Schramm RE, Reed RP. Stacking fault energies of seven commercial austenitic stainless steels. Metallurgical Transactions A. 1975;6:1345-1351. DOI: 10.1007/BF02641927

[3] Rhodes CG, Thompson AW. The composition dependence of stacking fault energy in austenitic stainless steels. Metallurgical Transactions A. 1977;8:1901-1906. DOI: 10.1007/ BF02646563

[4] Lo KH, Shek CH, Lai JKL. Recent developments in stainless steels. Materials Science \& Engineering R: Reports. 2009;65:39-104. DOI: 10.1016/j.mser.2009.03.001

[5] Yonezawa T, Suzuki K, Ooki S, Hashimoto A. The effect of chemical composition and heat treatment conditions on stacking fault energy for Fe-Cr-Ni austenitic stainless steel. Metallurgical and Materials Transactions A: Physical Metallurgy and Materials Science. 2013;44:5884-5896. DOI: 10.1007/s11661-013-1943-0

[6] Brofman PJ, Ansell GS. On the effect of carbon on the stacking fault energy of austenitic stainless steels. Metallurgical Transactions A. 1978;9:879-880. DOI: 10.1007/BF02649799

[7] Rémy L, Pineau A, Thomas B. Temperature dependence of stacking fault energy in close-packed metals and alloys. Materials Science and Engineering. 1978;36:47-63. DOI: 10.1016/0025-5416(78)90194-5

[8] Kestenbach H-J. The effect of applied stress on partial dislocation separation and dislocation substructure in austenitic stainless steel. Philosophical Magazine. 1977;36:15091515. DOI: $10.1080 / 14786437708238531$

[9] Roychowdhury S, Kain V, Neogy S, Srivastava D, Dey GK, Prasad RC. Understanding the effect of nitrogen in austenitic stainless steel on the intergranular stress corrosion crack growth rate in high temperature pure water. Acta Materialia. 2012;60:610-621. DOI: 10.1016/j.actamat.2011.09.053

[10] Pozuelo M, Wittig JE, Jiménez JA, Frommeyer G. Enhanced mechanical properties of a novel high-nitrogen Cr-Mn-Ni-Si austenitic stainless steel via TWIP/TRIP effects. Metallurgical and Materials Transactions A: Physical Metallurgy and Materials Science. 2009;40:1826-1834

[11] Breedis JF. Influence of dislocation substructure on the martensitic transformation in stainless steel. Acta Metallurgica. 1965;13:239-250. DOI: 10.1016/0001-6160(65)90201-4

[12] Abrassart F. Stress-induced $\gamma \rightarrow \alpha$ martensitic transformation in two carbon stainless steels. Application to trip steels. Metallurgical and Materials Transactions A. 1973;4:22052216. DOI: $10.1007 / \mathrm{BF} 02643289$

[13] Vogt J-B, Magnin T, Foct J. Effective stresses and microstructure in cyclically deformed 3161 austenitic stainless steel: Effect of temperature and nitrogen content. Fatigue and Fracture of Engineering Materials and Structures. 1993;16:555-564. DOI: 10.1111/j.14602695.1993.tb00766.x

[14] Mola J, Wendler M, Weiß A, Reichel B, Wolf G, De Cooman BC. Segregation-induced enhancement of low-temperature tensile ductility in a cast high-nitrogen austenitic 
stainless steel exhibiting deformation-induced $\alpha^{\prime}$ martensite formation. Metallurgical and Materials Transactions A: Physical Metallurgy and Materials Science. 2015;46(4): 1450. DOI: 10.1007/s11661-015-2782-y

[15] Rahimi R, Ullrich C, Klemm V, Rafaja D, De Cooman BC, Biermann H, et al. Influence of $\mathrm{Al}$ on the temperature dependence of strain hardening behavior and glide planarity in $\mathrm{Fe}-\mathrm{Cr}-\mathrm{Ni}-\mathrm{Mn}-\mathrm{C}$ austenitic stainless steels. Materials Science and Engineering A. 2016;649:301-312. DOI: 10.1016/j.msea.2015.10.005

[16] Rahimi R, Ullrich C, Rafaja D, Biermann H, Mola J. Microstructural evolution of an Al-alloyed duplex stainless steel during tensile deformation between $77 \mathrm{~K}$ and $473 \mathrm{~K}$ $\left(-196^{\circ} \mathrm{C}\right.$ and $\left.200{ }^{\circ} \mathrm{C}\right)$. Metallurgical and Materials Transactions A: Physical Metallurgy and Materials Science. 2016;47:2705-2716. DOI: 10.1007/s11661-016-3438-2

[17] Gutte H, Weiß A. Spannungs- und verformungsinduzierte Martensitbildungen in metastabilen austenitischen CrNi-Stählen. Habilitation: TU Bergakademie Freiberg; 2011

[18] Nikulin I, Sawaguchi T, Tsuzaki K. Effect of alloying composition on low-cycle fatigue properties and microstructure of Fe-30Mn-(6-x)Si-xAl TRIP/TWIP alloys. Materials Science and Engineering A. 2013;587:192-200. DOI: 10.1016/j.msea.2013.08.061

[19] Chen AY, Ruan HH, Wang J, Chan HL, Wang Q, Li Q, et al. The influence of strain rate on the microstructure transition of 304 stainless steel. Acta Materialia. 2011;59:3697-3709. DOI: 10.1016/j.actamat.2011.03.005

[20] Shen YF, Li XX, Sun X, Wang YD, Zuo L. Twinning and martensite in a 304 austenitic stainless steel. Materials Science and Engineering A. 2012;552:514-522. DOI: 10.1016/j. msea.2012.05.080

[21] Weidner A, Martin S, Klemm V, Martin U, Biermann H. Stacking faults in high-alloyed metastable austenitic cast steel observed by electron channelling contrast imaging. Scripta Materialia. 2011;64(6):513. DOI: 10.1016/j.scriptamat.2010.11.028

[22] Biermann H, Solarek J, Weidner A. SEM investigation of high-alloyed austenitic stainless cast steels with varying austenite stability at room temperature and $100^{\circ} \mathrm{C}$. Steel Research International. 2012;83:512-520. DOI: 10.1002/srin.201100293

[23] Wendler M, Hauser M, Fabrichnaya O, Krüger L, Weiß A, Mola J. Thermal and deformation-induced phase transformation behavior of Fe-15Cr-3Mn-3Ni-0.1N-(0.05-0.25) $\mathrm{C}$ austenitic and austenitic-martensitic cast stainless steels. Materials Science and Engineering A. 2015;645:28-39. DOI: 10.1016/j.msea.2015.07.084

[24] Peter Palzer. Bestimmung der Stickstofflöslichkeit im schmelzflüssigen und festen Zustand bei hochlegierten CrMnNi-Stahlgusslegierungen mit anschließender Charakterisierung der Mikrostruktur sowie der mechanischen Eigenschaften. Diploma Thesis. TU Bergakademie Freiberg, 2012.

[25] Wendler M, Reichel B, Krüger L, Weiß A, Mola J. Influence of Carbon on the Microstructure and Mechanical Properties of Cast Austenitic Fe-19Cr-4Ni-3Mn-0.15N Steels. Hamburg, Germany: HNS 2014. p. 2014 
[26] Hauser M, Wendler M, Ghosh Chowdhury S, Weiß A, Mola J. Quantification of deformation induced $\alpha^{\prime}$-martensite in Fe-19Cr-3Mn-4Ni-0.15C-0·15N austenitic steel by in situ magnetic measurements. Materials Science and Technology. 2015;31:1473-1478. DOI: $10.1179 / 1743284714 \mathrm{Y} .0000000731$

[27] Wendler M, Mola J, Reichel B, Krüger L, Weiß A. Temperature dependence of properties in an Fe-19Cr-4Ni-3Mn-0.15N-0.2C austenitic cast steel. Aachen: HMnS 2014; 2014. p. $407-410$

[28] Mola J, Ullrich C, Kuang B, Rahimi R, Huang Q, Rafaja D, et al. Austenitic nickel- and manganese-free Fe-15Cr-1Mo-0.4N-0.3C steel: Tensile behavior and deformationinduced processes between $298 \mathrm{~K}$ and $503 \mathrm{~K}\left(25^{\circ} \mathrm{C}\right.$ and $\left.230{ }^{\circ} \mathrm{C}\right)$. Metallurgical and Materials Transactions A: Physical Metallurgy and Materials Science. 2017;48:1033-1052. DOI: $10.1007 / \mathrm{s} 11661-017-3960-x$

[29] Olson GB, Cohen M. Kinetics of strain-induced martensitic nucleation. Metallurgical Transactions A. 1975;6:791-795. DOI: 10.1007/BF02672301

[30] Martin S, Wolf S, Martin U, Krüger L. Influence of temperature on phase transformation and deformation mechanisms of cast CrMnNi-TRIP/TWIP steel. Solid State Phenomena. 2011;172-174:172-177. DOI: 10.4028/www.scientific.net/SSP.172-174.172

[31] Talonen J, Hänninen H. Formation of shear bands and strain-induced martensite during plastic deformation of metastable austenitic stainless steels. Acta Materialia. 2007;55(18):6108. DOI: 10.1016/j.actamat.2007.07.015

[32] Bogers AJ, Burgers WG. Partial dislocations on the $\{110\}$ planes in the B.C.C. lattice and the transition of the F.C.C. into the B.C.C. lattice. Acta Metallurgica. 1964;12:255-261. DOI: 10.1016/0001-6160(64)90194-4

[33] Olson GB, Cohen M. A general mechanism of martensitic nucleation: Part II. FCC $\rightarrow$ BCC and other martensitic transformations. Metallurgical Transactions A. 1976;7:1905-1914

[34] Lee T-H, Ha H-Y, Kang J-Y, Moon J, Lee C-H, Park S-J. An intersecting-shear model for strain-induced martensitic transformation. Acta Materialia. 2013;61:7399-7410. DOI: 10.1016/j.actamat.2013.08.046

[35] Yang X-S, Sun S, X-L W, Ma E, Zhang T-Y. Dissecting the mechanism of martensitic transformation via atomic-scale observations. Scientific Reports. 2014;4:1-7. DOI: 10.1038/ srep06141

[36] KutschkeT.Untersuchung zur deformationsinduzierten Martensit-und Zwillingsbildung im Gusszustand des Cr-Mn-Ni Stahls 16-7-6. Diploma Thesis. TU Bergakademie Freiberg; 2011

[37] Weiß A, Gutte H, Mola J. Contributions of $\varepsilon$ and $\alpha^{\prime}$ TRIP effects to the strength and ductility of AISI 304 (X5CrNi18-10) austenitic stainless steel. Metallurgical and Materials Transactions A: Physical Metallurgy and Materials Science. 2016;47:112-122. DOI: 10.1007/s11661-014-2726-y 
[38] Hamada AS, Karjalainen LP, Misra RDK, Talonen J. Contribution of deformation mechanisms to strength and ductility in two Cr-Mn grade austenitic stainless steels. Materials Science and Engineering A. 2013;559:336-344. DOI: 10.1016/j.msea.2012.08.108

[39] Jahn A, Kovalev A, Weiß A, Wolf S, Krüger L, Scheller PR. Temperature depending influence of the martensite formation on the mechanical properties of high-alloyed $\mathrm{Cr}-\mathrm{Mn}-\mathrm{Ni}$ As-cast steels. Steel Research International. 2011;82:39-44. DOI: 10.1002/srin.201000228

[40] Kovalev A, Jahn A, Weiß A, Scheller PR. Characterization of the TRIP/TWIP effect in austenitic stainless steels using stress-temperature-transformation (STT) and deformation-temperature-transformation (DTT) diagrams. Steel Research International. 2011;82:45-50. DOI: 10.1002/srin.201000245

[41] Kovalev A, Jahn A, Weiß A, Wolf S, Scheller PR. Stress-temperature-transformation and deformation-temperature-transformation diagrams for an austenitic CrMnNi as-cast steel. Steel Research International. 2011;82:1101-1107. DOI: 10.1002/srin.201100065

[42] Kovalev A, Jahn A, Weiß A, Wolf S, Scheller PR. STT and DTT diagrams of austenitic $\mathrm{Cr}-\mathrm{Mn}-\mathrm{Ni}$ as-cast steels and crucial thermodynamic aspects of $\gamma \rightarrow \alpha^{\prime}$ transformation. Steel Research International. 2012;83:576-583. DOI: 10.1002/srin.201100267

[43] Wendler M, Weiß A, Krüger L, Mola J, Franke A, Kovalev A, et al. Effect of manganese on microstructure and mechanical properties of cast high alloyed CrMnNi-N steels. Advanced Engineering Materials. 2013;15:558-565. DOI: 10.1002/adem.201200318

[44] Zhang W, Hu J. Effect of annealing temperature on transformation induced plasticity effect of a lean duplex stainless steel. Materials Characterization. 2013;79:37-42. DOI: 10.1016/j.matchar.2013.02.003

[45] Lecroisey F, Pineau A. Martensitic transformations induced by plastic deformation in the Fe-Ni-Cr-C system. Metallurgical and Materials Transactions B. 1972;3:391-400. DOI: 10.1007/BF02642042

[46] Olson GB, Cohen M. A general mechanism of martensitic nucleation: Part I. General concepts and the FCC $\rightarrow$ HCP transformation. Metallurgical Transactions A. 1976;7:18971904. DOI: $10.1007 / \mathrm{BF} 02659822$

[47] Cohen JB, Weertman J. A dislocation model for twinning in f.c.c. metals. Acta Metallurgica. 1963;11(8):996. DOI: 10.1016/0001-6160(63)90074-9

[48] Lewis N, Cieslak MJ, Savage WF. Microsegregation and eutectic ferrite-to-austenite transformation in primary austenite solidified CF-8M weld metals. Journal of Materials Science. 1987;22:2799-2810. DOI: 10.1007/BF01086474

[49] Martin S, Fabrichnaya O, Rafaja D. Prediction of the local deformation mechanisms in metastable austenitic steels from the local concentration of the main alloying elements. Materials Letters. 2015;159:484-488. DOI: 10.1016/j.matlet.2015.06.087

[50] Sakuma Y, Matlock DK, Krauss G. Intercritically annealed and isothermally transformed 0.15 Pct C steels containing 1.2 Pct Si-1.5 Pct Mn and 4 Pct Ni: Part II. effect of testing 
temperature on stress-strain behavior and deformation-induced austenite transformation. Metallurgical Transactions A. 1992;23:1233-1241. DOI: 10.1007/BF02665054

[51] Feng W, Wu Z, Wang L, Speer JG. Effect of testing temperature on retained austenite stability of cold rolled CMnSi steels treated by quenching and partitioning process. Steel Research International. 2013;84:246-252. DOI: 10.1002/srin.201200129

[52] Byun TS, Hashimoto N, Farrell K. Temperature dependence of strain hardening and plastic instability behaviors in austenitic stainless steels. Acta Materialia. 2004;52:38893899. DOI: 10.1016/j.actamat.2004.05.003

[53] Shin HC, Ha TK, Chang YW. Kinetics of deformation induced martensitic transformation in a 304 stainless steel. Scripta Materialia. 2001;45:823-829. DOI: 10.1016/S13596462(01)01101-0

[54] Padilha AF, Rios PR. Decomposition of austenite in austenitic stainless steels. ISIJ International. 2002;42:325-337

[55] Bhadeshia HKDH, HoneycombeSR. 1 - Iron and its Interstitial Solid Solutions. In: Bhadeshia HKDH, Honeycombe SR, editors. Steels. 3rd ed. Oxford: Butterworth-Heinemann; 2006. p. $1-16$

[56] Kiani-Rashid AR, Edmonds DV. Phase transformation study of aluminium-containing ductile cast irons by dilatometry. Materials Science and Engineering A. 2008;481-482:752756. DOI: 10.1016/j.msea.2007.02.167

[57] Simmons JW. Overview: High-nitrogen alloying of stainless steels. Materials Science and Engineering A. 1996;207:159-169. DOI: 10.1016/0921-5093(95)09991-3

[58] Kim S-J, Lee T-H, Oh C-S. Effect of nitrogen on the deformation behaviour of highnitrogen austenitic stainless steels. Steel Research International. 2009;80:467-472. DOI: 10.2374/SRI09SP033

[59] Lee T-H, Ha H-Y, Hwang B, Kim S-J, Shin E, Lee JW. Scale-bridging analysis on deformation behavior of high-nitrogen austenitic steels. Microscopy and Microanalysis. 2013;19:77-82. DOI: 10.1017/S1431927613012385

[60] Berns H, Gavriljuk V, Riedner S. High Interstitial Stainless Austenitic Steels. Berlin, Heidelberg: Springer Berlin Heidelberg; 2013

[61] Huang Q, Volkova O, Biermann H, Mola J. Tensile elongation of lean-alloy austenitic stainless steels: Transformation-induced plasticity versus planar glide. Materials Science and Technology. 2017;0:1-7. DOI: 10.1080/02670836.2016.1277091 